\title{
Effect of advective pore water transport on distribution and degradation of diatoms in permeable North Sea sediments
}

\author{
Sandra Ehrenhauss ${ }^{1, *}$, Ursula Witte ${ }^{1}$, Solveig I. Bühring ${ }^{1}$, Markus Huettel ${ }^{1,2}$ \\ ${ }^{1}$ Max Planck Institute for Marine Microbiology, Celsiusstraße 1, 28359 Bremen, Germany \\ ${ }^{2}$ Florida State University, Department of Oceanography, Tallahassee, Florida 32306-4320, USA
}

\begin{abstract}
This contribution addresses the incorporation and degradation of diatoms in coastal fine, medium and coarse North Sea sands. During 3 cruises in 2001 to a highly dynamic, non-depositional area in the southern German Bight, the transport of ${ }^{13} \mathrm{C}$-labeled diatoms into these different permeable sand beds was assessed by in situ and on-board chamber experiments. Enhanced advective transport of diatom frustules and ${ }^{13} \mathrm{C}$-enriched diatom carbon into sandy sediments with increasing permeability was demonstrated. Highest transport rates were observed in medium and coarse sand, where $6 \%$ of the added algae were found below $1 \mathrm{~cm}$ after $20 \mathrm{~h}$ incubation. In the coarse sand, the high ratio between sand grain and particle size enhanced the delivery of algae to the sediment, but seemed to reduce the filtration efficiency and thus algal retention. Broken frustules of Thalassiosira sp., the diatom which dominated the diatom spring bloom in 2001, were found in the medium and coarse sand in autumn. This indicates that advective transport and, to some limited extent, bioturbation, deposits phytoplankton into these sandy sediments, where strong bottom currents theoretically would prevent the sedimentation of low-density organic material. The trapped cells are rapidly degraded, as observed in our chamber experiments, where $28 \%$ of the added diatom carbon was released as dissolved organic carbon (DOC) per day after the third incubation day. We conclude that permeable sediments represent expansive coastal filter systems, where high advective flushing rates boost remineralization of trapped algal cells. These processes promote a fast recycling of organic matter and, thus, may be important for maintaining high primary production rates in shelf environments.
\end{abstract}

KEY WORDS: German Bight · Permeable shelf sediments - Pore water flow · Planktonic diatoms · Benthic diatoms $\cdot{ }^{13} \mathrm{C}$-labeling $\cdot$ Remineralization $\cdot$ Carbon cycling

Resale or republication not permitted without written consent of the publisher

\section{INTRODUCTION}

The German Bight is a shallow region of the SE North Sea with depths mainly between 20 and $40 \mathrm{~m}$. This region is characterized by a high primary productivity and large standing stock of phytoplankton, except during the winter months (Boon et al. 1998). Offshore of Spiekeroog Island, near-bottom current velocities range from 30 to $60 \mathrm{~cm} \mathrm{~s}^{-1}$ (Antia 1993). In this highenergy environment, tides, waves and stormgenerated bottom currents cause frequent sediment erosion, redeposition and lateral transport, resulting in coarse-grained, highly permeable sediments (Antia
1995). Consequently, organic particulate material also goes through many cycles of deposition and resuspension before it is finally completely mineralized or buried (Bacon et al. 1994). For the southern North Sea, it has been postulated that only small amounts of primary production are incorporated into the sediments, because this material has to be transported to less turbulent zones where it can settle (Creutzberg \& Postma 1979). However, Jenness \& Duineveld (1985) demonstrated the deposition of considerable amounts of phytoplankton into sandy North Sea sediments without simultaneous mud deposition. In contrast to muddy, cohesive sediments, in which molecular diffusion is the 
major transport process for solutes through the sediment, advective transport processes gain significance in sediments with permeabilities exceeding $10^{-12} \mathrm{~m}^{2}$ (Huettel et al. 1998). The driving forces for these interstitial pore water flows are pressure gradients, which are generated when unidirectional or oscillating bottom currents interact with sediment topography, e.g. sediment ripples and biogenic structures (Huettel \& Webster 2001, Precht \& Huettel 2003). Advective pore water flows provide an effective transport mechanism for dissolved and particulate matter through the interstitial space (Huettel et al. 1998). Flume experiments have shown that such pore water flows enhance the nutrient release (Huettel et al. 1998) as well as oxygen penetration depth (Ziebis et al. 1996) and consumption (Forster et al. 1996) in permeable sediments. Advective transport of phytoplankton into permeable beds has been demonstrated in flume studies and in situ (Pilditch et al. 1998, Huettel \& Rusch 2000). Thus, the degradation of organic matter can be shifted from the sediment surface to deeper sediment layers, preventing resuspension of the material by waves and strong bottom currents (Huettel \& Rusch 2000).

Nevertheless, the organic carbon content of sandy sediments is generally low (Shum \& Sundby 1996), and this has led to the view that the biogeochemical activity in these beds also is low. However, a study of Grant et al. (1991) on oxygen consumption in shelf sediments revealed that the oxygen uptake in coarse sediment was only 2 to 3 times lower than the uptake in a nearby fine-grained sediment despite a 20 times higher carbon content. Consequently, the contribution of sandy sediments to organic matter degradation in the shallow shelf may be larger than inferred from the low organic content (Shum \& Sundby 1996).

Spring diatom blooms are often the events of highest yearly new production and carbon sedimentation in the coastal ocean (Goering et al. 1973). Planktonic diatoms do not have any structures facilitating locomotion, but considerable physiological control over buoyancy (Smayda 1970). As some of these controls are energy-dependent, sinking rates can increase drastically upon nutrient depletion (Smetacek 1985). Aggregation after intense blooms further can accelerate the sinking rates (Passow 1991). Several authors (Peinert et al. 1982, Brussaard et al. 1995) have shown that sedimentation, and not grazing, is the major loss factor of diatom spring blooms. The sinking dynamics of coastal bloom diatoms are an integral part of their life history and represent the transition from a reproductive pelagic stage to a benthic resting stage, which enables them to survive over long periods in cold, dark environments (Smetacek 1985).

In contrast to planktonic diatoms, benthic diatoms include motile and non-motile species. Epipelic spe cies (growing on mud), for example, are usually motile, while epipsammic species (growing on sand) are usually non-motile. Benthic diatoms are important primary producers in many estuarine, intertidal and shallowwater environments.

The purpose of this study was to assess the vertical distribution of diatoms in coastal sediments with different permeabilities, and the potential role of advective transport processes for this distribution. Therefore, we collected sediment cores in 3 nearshore subtidal sandy sediments that revealed the distribution and abundance of planktonic and benthic diatoms in the different sands. For the investigation of the entrainment depth and the timescale of the interfacial transport of planktonic diatoms into the different sands, we conducted 3 on-board and 2 in situ chamber experiments. The diatoms were labeled with ${ }^{13} \mathrm{C}$, permitting us to trace the pathway of the algal carbon within the sediment (Levin et al. 1997). In order to assess whether interfacial water flows enhance the degradation of the added diatoms, samples were analyzed for dissolved organic carbon (DOC) content.

\section{MATERIALS AND METHODS}

Study area. Sediment collection and experiments were carried out on nearshore subtidal sands during 3 cruises of RV 'Heincke' (HE 145, HE 148 and HE 154) to an area seawards of Spiekeroog Island (SE German Bight) (Fig. 1). This environment is strongly influenced by tides, waves and storm currents (Antia 1995). The mean tidal range at the study site is $2.5 \mathrm{~m}$. Salinity varied between 31 and 32 PSU.

For the measurements, in situ and on-board experiments, 3 well-studied sites (Antia 1993, 1995) with different sediment characteristics were chosen (Table 1), all located within a distance of $2500 \mathrm{~m}$ (Fig. 1).

Sediment collection. For the characterization and distribution of planktonic and benthic diatom species, 3 cores of fine sand, 3 cores of medium sand and 1 core of coarse sand were taken with a multiple corer on the September cruise (HE 154). These cores (10 cm length, $3.6 \mathrm{~cm}$ inner diameter) were sliced in intervals of $2 \times 0.5 \mathrm{~cm}$ and $9 \times 1 \mathrm{~cm}$ and analyzed in the same manner as described below for the chamber cores.

Cultivation of ${ }^{13} \mathbf{C}$-enriched phytoplankton. For the experiments, an axenic clone of Ditylum brightwellii (Bacillariophyceae: Biddulphiales) was cultured in sterile artificial seawater with a salinity of 33 PSU (Grasshoff et al. 1999) enriched with $\mathrm{f} / 2$ medium (Guillard \& Ryther 1962) at $25^{\circ} \mathrm{C}$. D. brightwellii is a common species in the German Bight (Drebes 1974), and was also abundant during the spring bloom in 
Table 1. Positions, sediment and water characteristics of study sites at SE corner of German Bight (Spiekeroog Island). Permeability $k$, porosity, median grain size and POC concentrations of the sediments are taken from Janssen et al. (unpubl. data). Samples for sediment and water characteristics were taken at the same time as the experimental sediment cores retrieved by divers. Sediment POC values were integrated over the upper 10 sediment $\mathrm{cm}$. For assessment of background diatom numbers and $\mathrm{PO}^{13} \mathrm{C}$ in the different sediments, additional sediment cores were taken with a multiple corer (fine and medium sand: $\mathrm{n}=3$; coarse sand: $\mathrm{n}=1$ )

\begin{tabular}{|c|c|c|c|c|c|c|c|c|c|c|}
\hline $\begin{array}{l}\text { Cruise } \\
\text { (date, 2001) }\end{array}$ & Position & $\begin{array}{l}\text { Sand } \\
\text { type }\end{array}$ & $\begin{array}{c}k \\
\left(10^{-12} \mathrm{~m}^{2}\right) \\
( \pm \mathrm{SD})\end{array}$ & $\begin{array}{c}\text { Porosity } \\
\text { (vol. \%) } \\
( \pm \mathrm{SD})\end{array}$ & $\begin{array}{c}\text { Median } \\
\text { grain size } \\
(\mu \mathrm{m})( \pm \mathrm{SD})\end{array}$ & $\begin{array}{l}\text { Water } \\
\text { depth } \\
(\mathrm{m}) \\
( \pm \mathrm{SD})\end{array}$ & $\begin{array}{l}\text { Water } \\
\text { temp. } \\
\left({ }^{\circ} \mathrm{C}\right) \\
( \pm \mathrm{SD})\end{array}$ & $\begin{array}{c}\text { Bottom } \\
\text { water POC } \\
\left(\mathrm{mg} \mathrm{l}^{-1}\right)\end{array}$ & $\begin{array}{l}\text { Sediment } \\
\text { POC ( } \% \\
\text { dry mass) }\end{array}$ & $\begin{array}{l}\text { Chamber } \\
\text { experiment } \\
\text { with diatoms }\end{array}$ \\
\hline $\begin{array}{l}\text { HE } 145 \\
\text { (8-18 Apr) }\end{array}$ & $\begin{array}{l}53^{\circ} 51^{\prime} \mathrm{N} \\
7^{\circ} 44^{\prime} \mathrm{E}\end{array}$ & Fine & $\begin{array}{c}3.02 \\
( \pm 1.66)\end{array}$ & $\begin{array}{c}37.3 \\
( \pm 0.9)\end{array}$ & $\begin{array}{l}164 \\
( \pm 1)\end{array}$ & 19 & 9 & $\begin{array}{c}0.96 \\
( \pm 0.02)\end{array}$ & n.a. & $\begin{array}{c}\text { On board }(12 \mathrm{~h}, \\
\left.30 \mathrm{~h}, 132 \mathrm{~h}_{i} \mathrm{n}=2\right)\end{array}$ \\
\hline $\begin{array}{l}\text { HE } 148 \\
\text { (07-15 Jun) }\end{array}$ & $\begin{array}{c}53^{\circ} 51^{\prime} \mathrm{N} \\
7^{\circ} 44^{\prime} \mathrm{E}\end{array}$ & Fine & $\begin{array}{c}3.02 \\
( \pm 1.66)\end{array}$ & $\begin{array}{l}37.3 \\
( \pm 0.9)\end{array}$ & $\begin{array}{l}164 \\
( \pm 1)\end{array}$ & 19 & 13 & $\begin{array}{c}1.22 \\
( \pm 0.06)\end{array}$ & $\begin{array}{c}0.114 \\
( \pm 0.014)\end{array}$ & In situ $\left(32 \mathrm{~h}_{i} \mathrm{n}=2\right)$ \\
\hline \multirow[t]{2}{*}{$\begin{array}{l}\text { HE } 154 \\
\qquad(24-30 \text { Sep) }\end{array}$} & $\begin{array}{c}53^{\circ} 50^{\prime} \mathrm{N} \\
7^{\circ} 45^{\prime} \mathrm{E}\end{array}$ & Medium & $\begin{array}{c}26.27 \\
( \pm 3.26)\end{array}$ & $\begin{array}{c}33.9 \\
( \pm 0.6)\end{array}$ & $\begin{array}{l}299 \\
( \pm 3)\end{array}$ & 16 & 16 & $\begin{array}{c}0.61 \\
( \pm 0.03)\end{array}$ & $\begin{array}{c}0.023 \\
( \pm 0.003)\end{array}$ & $\begin{array}{l}\text { On board (12 h, } \\
\left.25 \mathrm{~h}, 72 \mathrm{~h}_{;} \mathrm{n}=1\right)+ \\
\text { in situ }(20 \mathrm{~h} ; \mathrm{n}=2)\end{array}$ \\
\hline & $\begin{array}{c}53^{\circ} 49.5^{\prime} \mathrm{N} \\
7^{\circ} 44.5^{\prime} \mathrm{E}\end{array}$ & Coarse & $\begin{array}{c}77.24 \\
( \pm 14.36)\end{array}$ & $\begin{array}{c}33.3 \\
( \pm 0.6)\end{array}$ & $\begin{array}{c}672 \\
( \pm 37)\end{array}$ & 14 & 16 & $\begin{array}{c}0.61 \\
( \pm 0.03)\end{array}$ & $\begin{array}{c}0.032 \\
( \pm 0.003)\end{array}$ & $\begin{array}{c}\text { On board } \\
\left(20 \mathrm{~h}_{\mathrm{i}} \mathrm{n}=1\right)\end{array}$ \\
\hline
\end{tabular}

1998 near our station $\left(53^{\circ} 53^{\prime} \mathrm{N}, 7^{\circ} 32^{\prime} \mathrm{E}\right)$ (Lo 1999). The medium contained $25 \%{ }^{13} \mathrm{C}$-enriched bicarbonate (through addition of $99 \% \mathrm{NaH}^{13} \mathrm{CO}_{3}$, Cambridge Isotope Laboratories). The algal material was harvested by centrifugation $(404 \times g, 4 \mathrm{~min})$, rinsed 3 times with an isotone sodium chloride solution, and centrifuged again. From this concentrated material, samples for dry mass, particulate organic carbon (POC), DOC, diatom numbers and labeling efficiency were taken, and the algae were then stored frozen until use. This treatment killed the diatoms and caused breakage of some cells, as

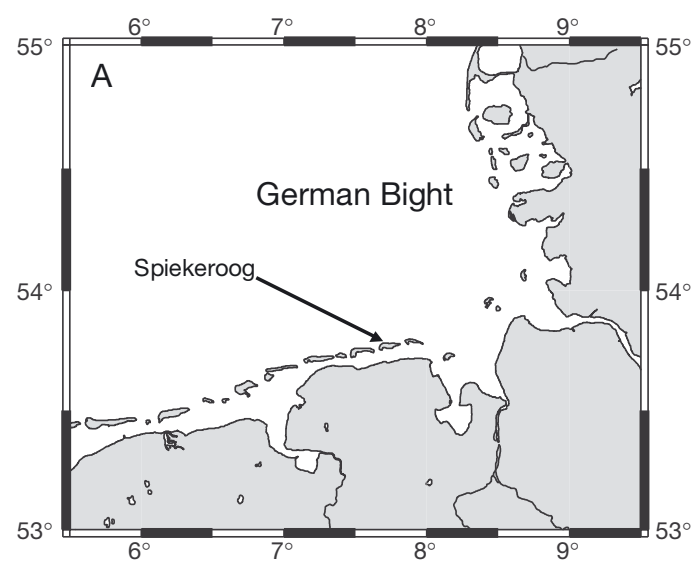

Fig. 1. (A) Location of Spiekeroog Island in German Bight (SE North Sea). (B) Bathymetry of Spiekeroog shoreface as given by Antia (1993), and locations of the 3 stations: $(\mathbf{O})$ station with fine sand; $(\mathbf{\Delta})$ station with medium sand; ( $\square$ ) station with coarse sand. Stippled areas represent sand bars observed under the microscope, which led to release of DOC from the cells (19 $\pm 7 \%$ of the added carbon). The axenic state of the culture was verified by microscopic observation of DAPI-stained cells. The produced algal carbon contained $15 \% \delta^{13} \mathrm{C}$ (HE 145),

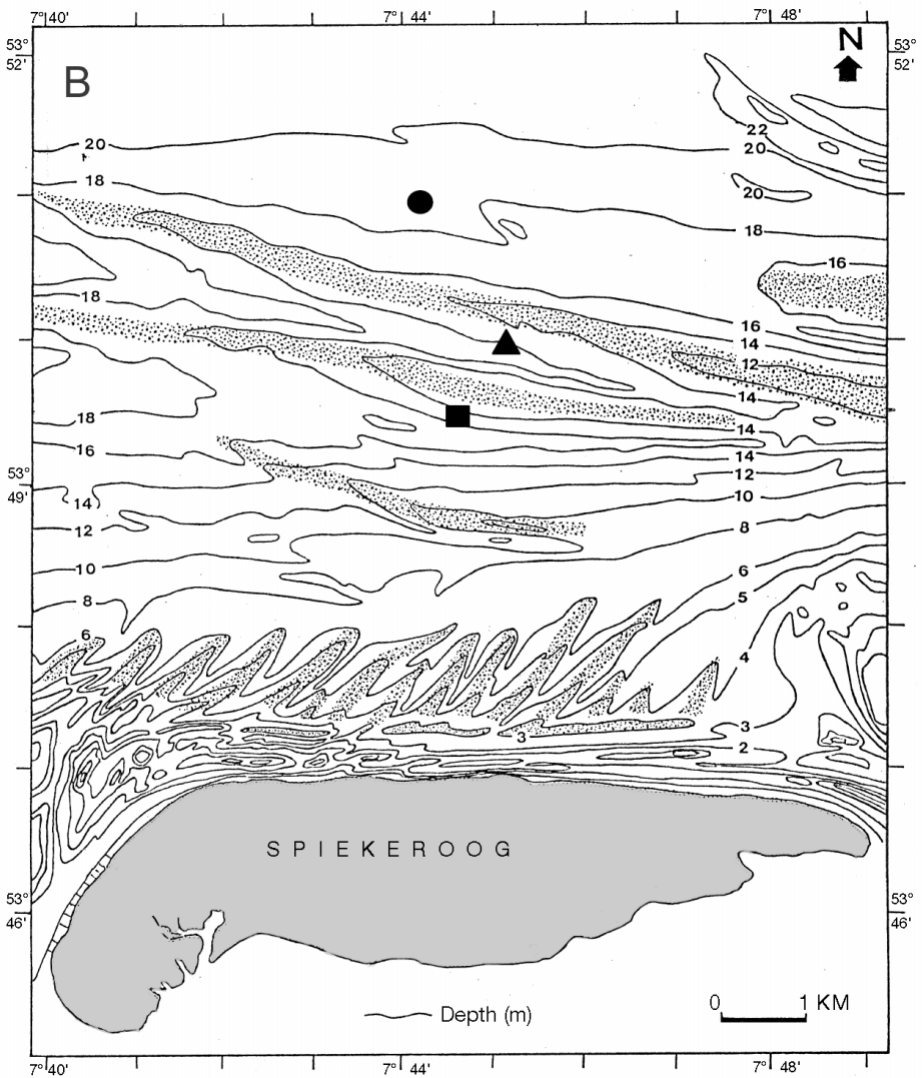


$9 \% \delta^{13} \mathrm{C}$ (HE 148) and $10 \% \delta^{13} \mathrm{C}$ (HE 154), and the carbon content of the added algae per chamber corresponded to $0.31 \mathrm{~g} \mathrm{C} \mathrm{m}^{-2}$ (HE 145), $0.36 \mathrm{~g} \mathrm{C} \mathrm{m}^{-2}$ (HE 148) and $0.50 \mathrm{~g} \mathrm{C} \mathrm{m}^{-2}$ (HE 154).

Experiments. Both in situ and on-board experiments were carried out in acrylic cylindrical chambers $(31 \mathrm{~cm}$ height, $19 \mathrm{~cm}$ inner diameter), which were covered by black foil, preventing any light penetration to the incubated water and sediments. The water inside each chamber was stirred by a horizontal disk $(17 \mathrm{~cm}$ diameter), rotating approximately $10 \mathrm{~cm}$ above the sediment surface at $20 \mathrm{rpm}$. The sediment height in each chamber was approximately $15 \mathrm{~cm}$. The rotating water generates a pressure gradient (ca. $0.2 \mathrm{~Pa} \mathrm{~cm}^{-1}$ ), comparable to the pressure gradient at a sediment ripple interacting with bottom currents (Huettel \& Rusch 2000). This pressure gradient creates advective pore water flows in permeable sediments.

The chambers were deployed and recovered by divers; for the in situ experiments, the algae were directly injected into the chambers by the divers, who sealed the chambers afterwards. Oxygen did not become limiting during the incubation time (always above $75 \mu \mathrm{M} \mathrm{O}_{2}$ ), as verified by determination of the final oxygen concentrations in the chamber water using the Winkler method (Grasshoff et al. 1999). At the end of the incubation time of $2 \times 32 \mathrm{~h}$ (fine sand, HE 148) and $2 \times 20 \mathrm{~h}$ (medium sand, HE 154), the chambers were closed at the bottom with sealing lids and brought back to the RV 'Heincke'. For the assessment of background values, bottom water was collected $2 \mathrm{~m}$ above the seafloor with a rosette equipped with 101 Niskin bottles at the beginning of the in situ experiments.

The sediment for the on-board incubations was cored and recovered by the divers using the same benthic chambers. On board, the chambers were kept at in situ temperature, and stirring was started immediately. Between the lid of the chambers and the water surfaces, an air-filled space of $4 \mathrm{~cm}$ was left to permit gas exchange. The on-board experiments ran for $2 \times 12 \mathrm{~h}$, $2 \times 30 \mathrm{~h}$ and $2 \times 132 \mathrm{~h}$ (fine sand, HE 145); for $12 \mathrm{~h}, 25 \mathrm{~h}$ and $72 \mathrm{~h}$ (medium sand, HE 154); and $20 \mathrm{~h}$ (coarse sand, HE 154). During these time periods, water samples for diatom numbers, DOC and bacterial numbers were taken with a syringe connected to a tube, at regular time intervals. The sampled water volume was replaced by $0.2 \mu \mathrm{m}$-filtered seawater and all results were corrected for this dilution. For the in situ experiments, these samples were only taken at the end of the incubation time.

At the end of all experiments, the entire cores were sliced at intervals of $10 \times 1 \mathrm{~cm}$ and $2 \times 2.5 \mathrm{~cm}$. Every depth interval was carefully mixed and samples for diatom numbers and ${ }^{13} \mathrm{C}$ of particulate organic carbon
$\left(\mathrm{PO}^{13} \mathrm{C}\right)$ were taken. In order to assess the background $\mathrm{PO}^{13} \mathrm{C}$ values without organic matter addition, 3 (fine and medium sand) or 1 (coarse sand) additional sediment cores were taken with a multiple corer for each experiment. These cores were sliced and analyzed in the same manner as described for the chamber cores.

Analytical techniques. Water samples for diatom numbers were preserved with hexamethylenetetramine buffered formaldehyde (end concentration $2 \%$ ) and Lugol's solution (end concentration 1\%) and kept refrigerated in dark glass bottles until analysis. To separate the algae from the sand grains, $1 \mathrm{ml}$ sediment was resuspended 2 times in $5 \mathrm{ml} 0.2 \mu \mathrm{m}$-filtered seawater, containing formaldehyde and Lugol's solution in the same final concentrations as for the water samples. The supernatant was collected after $30 \mathrm{~s}$ of deposition time and filtered on black membrane filters $(0.2 \mu \mathrm{m})$. All diatom cells of 20 randomly chosen counting grids of 3 parallel filters per sample were counted under a Zeiss $^{\mathrm{TM}}$ Axiophot epifluorescence microscope (excitation wave length 510 to $560 \mathrm{~nm}$, magnification 1300×). Diatom species were identified (Drebes 1974, Pankow 1990) using a Zeiss ${ }^{\mathrm{TM}}$ inverted microscope and the method of Utermöhl (1958) at a magnification of 400×.

To test the extraction efficiencies, a known concentration of a Ditylum brightwellii culture was added to the various sediments and incubated for $1 \mathrm{~d}$ in the dark. Diatom cells were extracted with $0.2 \mu \mathrm{m}$-filtered seawater as described above. Extraction efficiencies were: $76 \pm 5 \%$ (fine sand), $82 \pm 14 \%$ (medium sand), $79 \pm 9 \%$ (coarse sand).

For the dry mass determination of the Ditylum brightwellii culture, $1 \mathrm{ml}$ sample was filtered on precombusted $\left(500^{\circ} \mathrm{C}, 6 \mathrm{~h}\right)$, pre-weighed $\mathrm{GF} / \mathrm{F}$ filters, rinsed with distilled water to remove the sodium chloride, dried for $24 \mathrm{~h}$ at $60^{\circ} \mathrm{C}$ and weighed again.

Samples for the carbon content of the culture were filtered on precombusted GF/F filters, pre-treated with $0.1 \mathrm{~N} \mathrm{HCl}$ for $2 \mathrm{~h}$ to remove the bicarbonate and dried at $60^{\circ} \mathrm{C}$. Filters were then transferred into tin cups. The particulate organic carbon was measured using a Fisons $^{\text {TM }}$ NA1500 elemental analyzer.

For the assessment of the label efficiency of the culture, samples were combusted in a CE Instruments ${ }^{\mathrm{TM}} \mathrm{CHN}$-analyzer and the evolved $\mathrm{CO}_{2}$ was passed online via a ThermoFinnigan ${ }^{\mathrm{TM}}$ interface to a ThermoFinnigan $^{\mathrm{TM}}$ isotope-ratio mass spectrometer (IRMS) in a continuous flow of helium.

Samples for the $\delta^{13} \mathrm{C}$ values and concentration of the sediment POC were stored frozen in precombusted dark glass vials until processing. About $2 \mathrm{~g}$ sediment was dried for $48 \mathrm{~h}$ at $60^{\circ} \mathrm{C}$ and pre-treated with approximately $10 \mathrm{ml} 2 \mathrm{M} \mathrm{HCl}$ overnight to remove the bicarbonate. Sediments were then centrifuged $(2800 \times g$, 
$10 \mathrm{~min})$, washed 3 times with distilled water, centrifuged and dried again. Approximately $100 \mathrm{mg}$ of the sediment were exactly weighed into tin cups, and samples were measured as described for the label efficiency.

Carbon isotope ratios $\left({ }^{13} \mathrm{C} /{ }^{12} \mathrm{C}\right)$ are expressed in the conventional delta notation $\left(\delta^{13} \mathrm{C}\right)$ relative to Vienna $\operatorname{PDB}\left({ }^{13} \mathrm{C} /{ }^{12} \mathrm{C}_{\mathrm{VPDB}}=0.0112\right): \delta^{13} \mathrm{C}(\%)=\left[\left(\mathrm{R}_{\text {sample }} / \mathrm{R}_{\mathrm{std}}\right)-\right.$ $1)] \times 1000$, where $R_{\text {sample }}$ and $R_{\text {std }}$ are the ${ }^{13} \mathrm{C} /{ }^{12} \mathrm{C}$ of the sample and standard, respectively (Craig 1957). Incorporation of ${ }^{13} \mathrm{C}$ is shown as excess (above background) ${ }^{13} \mathrm{C}$ uptake, and was calculated according to Moodley et al. (2000) as the product of the POC concentration and excess ${ }^{13} \mathrm{C}(E) . E$ is the difference between the fraction $(F)$ of the sample and back-

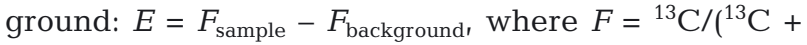
$\left.{ }^{12} \mathrm{C}\right)=R /(R+1)$ and $R=$ the carbon isotope ratio. $R$ was derived from the measured $\delta^{13} \mathrm{C}$ values as $R=$ $\left(\delta^{13} \mathrm{C} / 1000+1\right) \times R_{\mathrm{VPDB}}$.

Water samples for DOC were filtered through precombusted GF/F filters into precombusted $4 \mathrm{ml}$ glass vials and stored frozen until analysis. The DOC concentration was measured by high-temperature catalytic oxidation using a Shimadzu ${ }^{\mathrm{TM}}$ TOC-5050A analyzer. We measured 3 parallels per sample.

For the bacteria counts, water samples were preserved with formaldehyde (end concentration 4\%) and kept at $4^{\circ} \mathrm{C}$. Bacteria were filtered on black membrane filters $(0.2 \mu \mathrm{m})$, stained with acridine orange, and 20 randomly chosen counting grids of 3 parallel filters per sample were counted under a Zeiss $^{\mathrm{TM}}$ Axiophot epifluorescence microscope (excitation wavelength 450 to $490 \mathrm{~nm}$, magnification $1300 \times$ ).

\section{RESULTS \\ Distribution of planktonic and benthic diatoms in coastal North Sea sediments of different permeabilities}

In general, the medium and coarse sands showed a higher diversity of planktonic and benthic diatom species than the fine sand. Furthermore, the penetration depths of single diatom cells and diatom chains were higher in the coarse-grained sands.

The 2 major taxonomic divisions, centric (Centrales, Fig. 2) and pennate (Pennales, Fig. 3) diatoms also reflect a major ecological difference, as Pennales are mainly benthic and Centrales are mainly planktonic (Schrader \& Schuette 1981). This division was applicable for most species we identified, with the exception of Plagiogramma brockmanni, Nitzschia spp. (Pennales) and Actinoptychus senarius (Centrales), which have been reported as both, benthic and planktonic forms (Drebes 1974). The maximum penetration depth of the dominant planktonic diatom Coscinodiscus spp. increased with increasing sediment permeability: 2, 7 and $8 \mathrm{~cm}$ (total sampling depth) for the fine, medium and coarse sand, respectively (Fig. 2). Broken parts of diatom frustules from mainly centric species were abundant in relatively high numbers in the medium and coarse sand.

In the medium and coarse sands (Fig. 3), 4 different pennate diatom species were found, while in the fine sand only 2 different species occurred. The non-motile diatom Plagiogramma brockmanni was the dominant
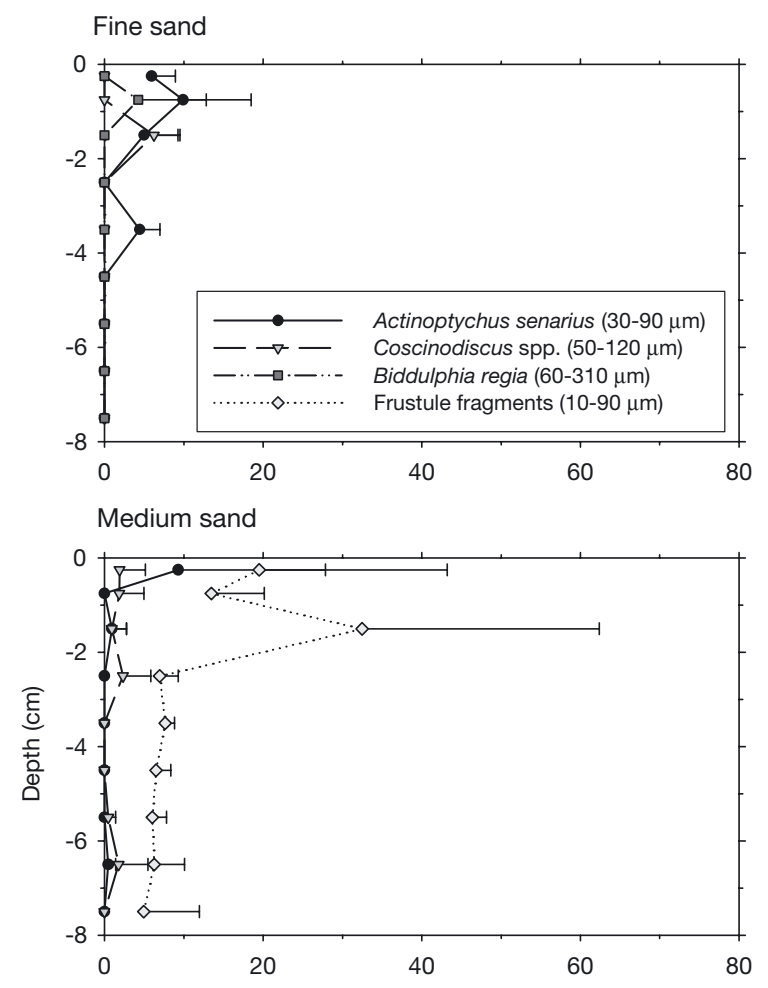

Coarse sand

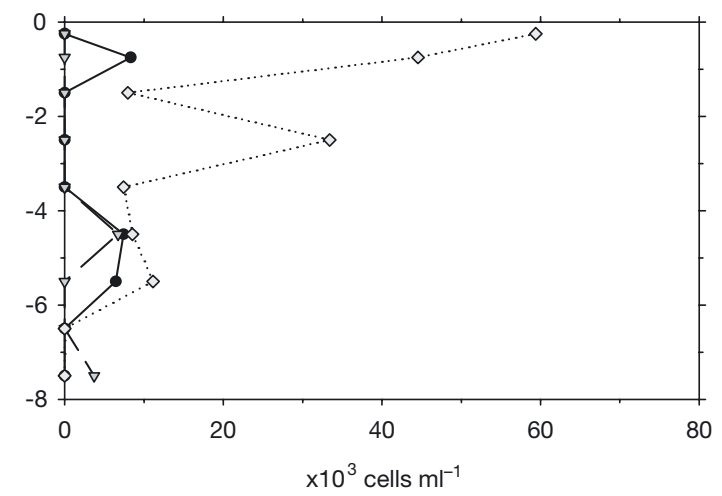

Fig. 2. Vertical distributions and averaged cell numbers (+SD) of centric diatom species in fine, medium and coarse sand. Sediment cores (fine and medium sand: $\mathrm{n}=3$; coarse sand: $\mathrm{n}=1$ ) were collected in September 2001 


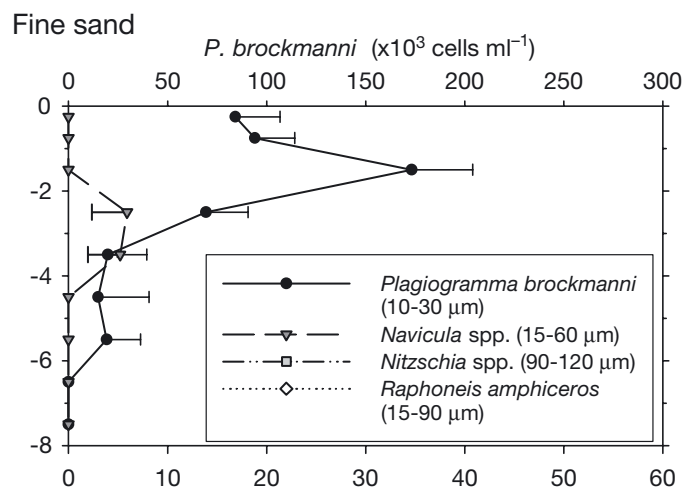

Medium sand
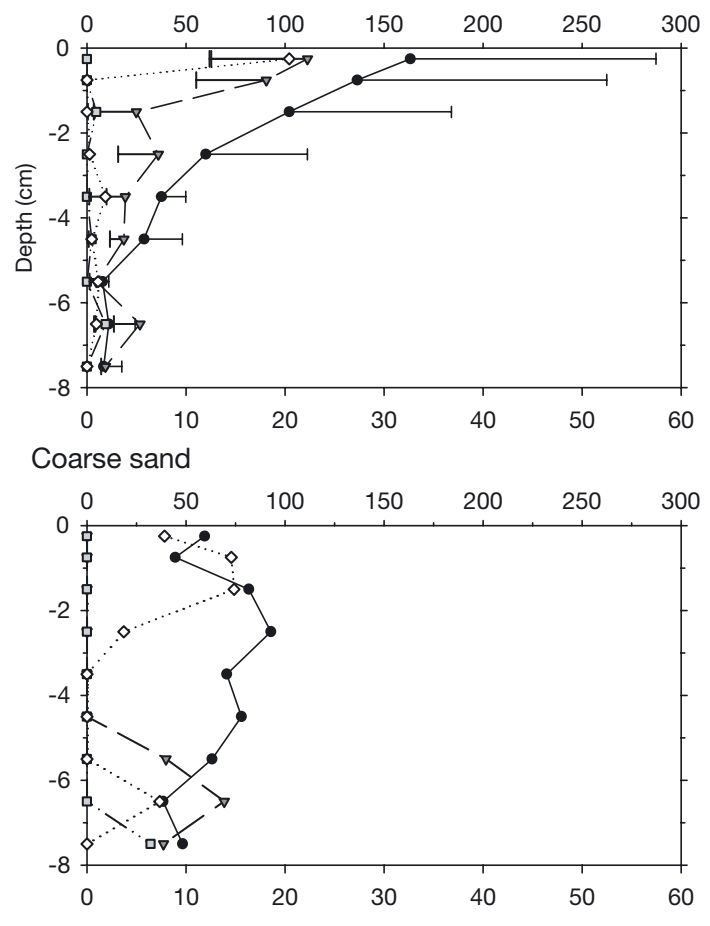

Other diatoms $\left(\times 10^{3}\right.$ cells $\left.\mathrm{ml}^{-1}\right)$

Fig. 3. Vertical distributions and averaged cell numbers of pennate diatom species in fine, medium and coarse sand. Sediment cores (fine and medium sand: $\mathrm{n}=3$; coarse sand: $\mathrm{n}=1$ ) were collected in September 2001. Upper abscissa scale: Plagiogramma brockmanni numbers (+SD); lower abscissa scale: other pennate diatoms (-SD)

pennate diatom species in all 3 sands, and its abundances were higher compared to the dominant centric diatom species. P. brockmanni belongs to the nonmotile epipsammic diatom species (Schrader \& Schuette 1981), and the single cells are united in long chains (Drebes 1974). The maximum cell number united in a chain did not exceed 5 cells for the fine sand, whereas chains of 9 and 10 cells were found in the medium and coarse sand, respectively (Fig. 4). The maximum penetration depth of single cells and chains of $P$. brockmanni both showed a positive correlation with sediment permeability (Fig. 5).

\section{Transport of ${ }^{13} \mathrm{C}$-labeled diatoms into sandy sediments of different permeabilities}

In all incubations we observed higher penetration depths of Ditylum brightwellii cells into the medium and coarse sand compared to the fine sand. This result was supported by the excess ${ }^{13} \mathrm{C}$ data, which showed enhanced transport of algal carbon into deeper layers of the coarse-grained sands.

Flux of Ditylum brightwellii cells from the water column into or onto the sediment increased with increasing sediment permeability (Table 2). The transport of $D$. brightwellii cells into the fine sand was restricted to the upper $2 \mathrm{~cm}$ of the sediment, with most cells accumulated in the upper $1 \mathrm{~cm}$ (Fig. 6) and less than $3.6 \%$ of the added diatoms found below $1 \mathrm{~cm}$ (Table 3). Algal penetration depth did not increase with increasing incubation time. After an incubation time of $132 \mathrm{~h}$, the bulk of diatom cells still was found in the uppermost $1 \mathrm{~cm}$ of the fine sand and only $1.5 \%$ of the added diatoms were found below $1 \mathrm{~cm}$ (Table 3 ). Highest cell numbers were also observed in the upper $1 \mathrm{~cm}$ sediment in the incubations with medium sand, but with increased incubation time more cells, corresponding to $6.2 \%(20 \mathrm{~h})$ and $14.3 \%(72 \mathrm{~h})$ of the added diatom cells, were transported below $1 \mathrm{~cm}$ depth of the medium sand (Table 3). Comparable transport rates were recorded in the coarse sand, where $5.8 \%$ of the added algae were found below $1 \mathrm{~cm}$ after $20 \mathrm{~h}$ incubation time. Lower total recovery rates of diatoms in the fine sand compared to the coarse-grained sands (Table 3) may be a result of lower extraction efficiencies (see 5th subsection of 'Materials and methods') and higher uptake by macro-

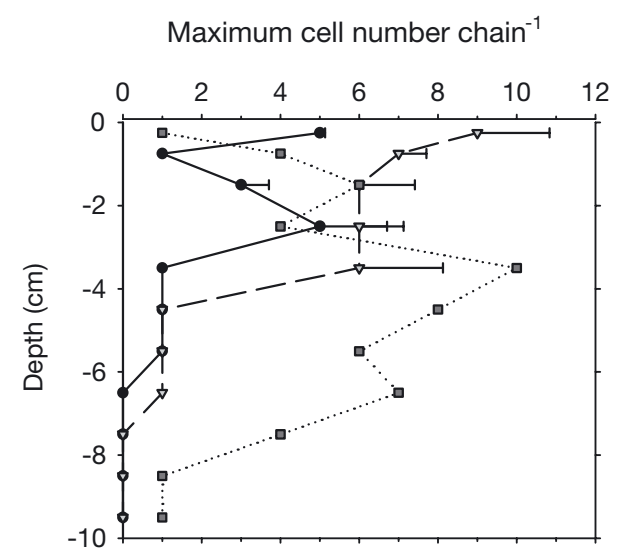

Fig. 4. Plagiogramma brockmanni. Maximum cell number in chains $(+\mathrm{SD})$ of dominant diatom species in fine $(\bullet)$, medium $(\nabla)$ and coarse ( $\square$ ) sand 
fauna, whose biomass were significantly higher on the fine sand (U. Witte et al. unpubl. data).

Total uptake of excess ${ }^{13} \mathrm{C}$ into the fine sand (Fig. 6) was mainly restricted to the upper $2 \mathrm{~cm}$ of the sediment after $12 \mathrm{~h}$. With increasing incubation time (30 to $132 \mathrm{~h}$ ), more excess ${ }^{13} \mathrm{C}$ could be detected in deeper sediment layers (2 to $6 \mathrm{~cm}$ ), but the bulk of diatom carbon still accumulated in the surface layer. In the $12 \mathrm{~h}$ incubation with medium sand, highest amounts of excess ${ }^{13} \mathrm{C}$ were also detected in the upper $2 \mathrm{~cm}$, but with increasing incubation time $(72 \mathrm{~h})$ excess ${ }^{13} \mathrm{C}$ was transported deeper into the sediment $(12 \mathrm{~cm})$ (Fig. 6). In the incubation with coarse sand $(20 \mathrm{~h})$ the labeled algal carbon was found in depths of up to $3 \mathrm{~cm}$ (Fig. 6).

These results indicate enhanced transport of diatom cells and carbon into deeper sediment layers with increasing permeability (Fig. 7).

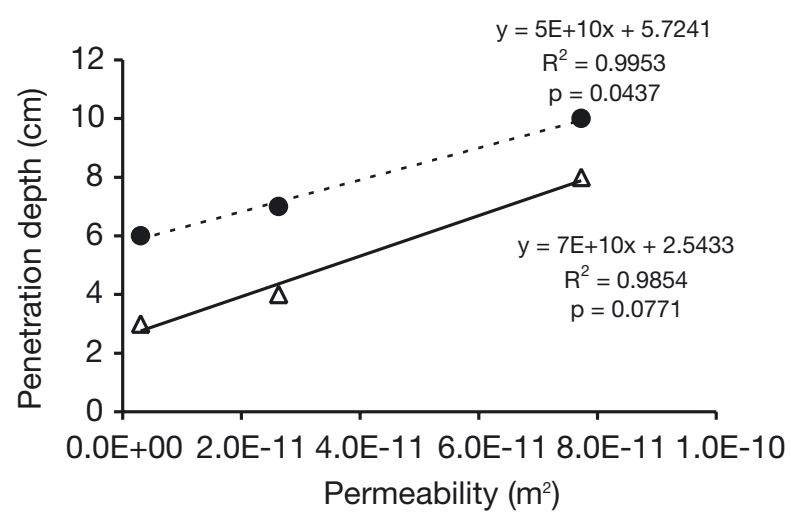

Fig. 5. Plagiogramma brockmanni. Maximum penetration depth of cells $(\boldsymbol{O})$ and chains $(\boldsymbol{\Delta})$ as a function of sediment permeability

Table 2. Initial Ditylum brightwellii cell concentration in water column and flux of cells into or onto sediment, increase of bacteria, DOC flux and $\mathrm{pH}$ changes measured in water column of all on-board incubations. Change in cell numbers is given for first $12 \mathrm{~h}$ of experiment. No cells were found in water column after $17 \mathrm{~h}$ (fine sand) and $12 \mathrm{~h}$ (medium and coarse sand), respectively. Positive values represent increase, negative values indicate decrease, $\mathrm{pH}$ values are for total incubation time; $\mathrm{pH}$ at beginning of experiment was approximately 8

\begin{tabular}{|c|c|c|c|c|c|}
\hline Sand type & $\begin{array}{l}\text { Initial } D \text {. brightwellii } \\
\text { concentration }( \pm \mathrm{SD}) \\
\quad\left(\times 10^{3} \text { cells } \mathrm{m}^{-2}\right)\end{array}$ & $\begin{array}{l}\text { D. brightwellii flux } \\
\left(\times 10^{3} \text { cells } \mathrm{m}^{-2} \mathrm{~d}^{-1}\right)\end{array}$ & $\begin{array}{c}\text { Bacteria } \\
\left(\times 10^{5}{\left.\text { cells } \mathrm{ml}^{-1} \mathrm{~h}^{-1}\right)}^{-1}\right)\end{array}$ & $\begin{array}{c}\text { DOC } \\
\left(\mu \mathrm{mol} \mathrm{m} \mathrm{m}^{-2} \mathrm{~d}^{-1}\right)\end{array}$ & $\begin{array}{c}\mathrm{pH} \\
\left(\mathrm{pH} \text { units } \mathrm{d}^{-1}\right)\end{array}$ \\
\hline Fine & $758( \pm 126)$ & -1070 & 1.35 & $\begin{array}{l}-1306 \text { (first } 72 \mathrm{~h}) \\
+7183(72-132 \mathrm{~h})\end{array}$ & -0.07 \\
\hline Medium & $604( \pm 72)$ & -1208 & 0.55 & $-1326(72 \mathrm{~h})$ & -0.05 \\
\hline Coarse & 776 & -1552 & 1.02 & $-1728(20 \mathrm{~h})$ & -0.09 \\
\hline
\end{tabular}

Table 3. Transport rates of Ditylum brightwellii cells (\% of total added algal cells) and $\mathrm{PO}^{13} \mathrm{C}$ (\% of total added algal $\mathrm{TO}{ }^{13} \mathrm{C}$ ) into different sediments. Recovery rate of total algal cells in the sediment was between 10 and 36\% (fine sand), 50 to $82 \%$ (medium sand) and $43 \%$ (coarse sand); recovery rate of $\mathrm{PO}^{13} \mathrm{C}$ in the sediment was between 1.2 and $1.5 \%$ (fine sand), 2.4 to $5.2 \%$ (medium sand) and $4.9 \%$ (coarse sand)

\begin{tabular}{|c|c|c|c|c|c|c|}
\hline \multirow{2}{*}{ Time } & \multicolumn{2}{|c|}{ Fine sand $(\% \pm$ range $)$} & \multicolumn{2}{|c|}{ Medium sand $(\% \pm$ range $)$} & \multicolumn{2}{|c|}{ Coarse sand (\%) } \\
\hline & Cells & $\mathrm{PO}^{13} \mathrm{C}$ & Cells & $\mathrm{PO}^{13} \mathrm{C}$ & Cells & $\mathrm{PO}^{13} \mathrm{C}$ \\
\hline \multicolumn{7}{|c|}{ 0-1 cm depth } \\
\hline $12 \mathrm{~h}$ & $32.2 \pm 10.5$ & $1.38 \pm 1.72$ & 67.6 & 2.23 & & \\
\hline $20 \mathrm{~h}$ & & & $76.2 \pm 5.5$ & $1.03 \pm 0.16$ & 37.6 & 4.48 \\
\hline $25 \mathrm{~h}$ & & & 49.7 & 4.68 & & \\
\hline $30 \mathrm{~h}$ & $31.9 \pm 7.3$ & $0.50 \pm 0.10$ & & & & \\
\hline $32 \mathrm{~h}$ & $8.1 \pm 2.2$ & $0.53 \pm 0.02$ & & & & \\
\hline $72 \mathrm{~h}$ & & & 67.3 & 3.62 & & \\
\hline $132 \mathrm{~h}$ & $21.2 \pm 4.1$ & $0.65 \pm 0.36$ & & & & \\
\hline \multicolumn{7}{|c|}{ 1-4 cm depth } \\
\hline $12 \mathrm{~h}$ & $3.6 \pm 0.7$ & $0.10 \pm 0.17$ & 5.3 & 0.81 & & \\
\hline $20 \mathrm{~h}$ & & & $6.2 \pm 3.0$ & $1.38 \pm 1.96$ & 5.8 & 0.42 \\
\hline $25 \mathrm{~h}$ & & & 0.0 & 0.50 & & \\
\hline $30 \mathrm{~h}$ & $0.0 \pm 0.0$ & $0.68 \pm 1.04$ & & & & \\
\hline $32 \mathrm{~h}$ & $2.4 \pm 0.9$ & $0.69 \pm 0.98$ & & & & \\
\hline $72 \mathrm{~h}$ & & & 14.3 & 0.93 & & \\
\hline $132 \mathrm{~h}$ & $1.5 \pm 0.7$ & $0.73 \pm 2.84$ & & & & \\
\hline
\end{tabular}



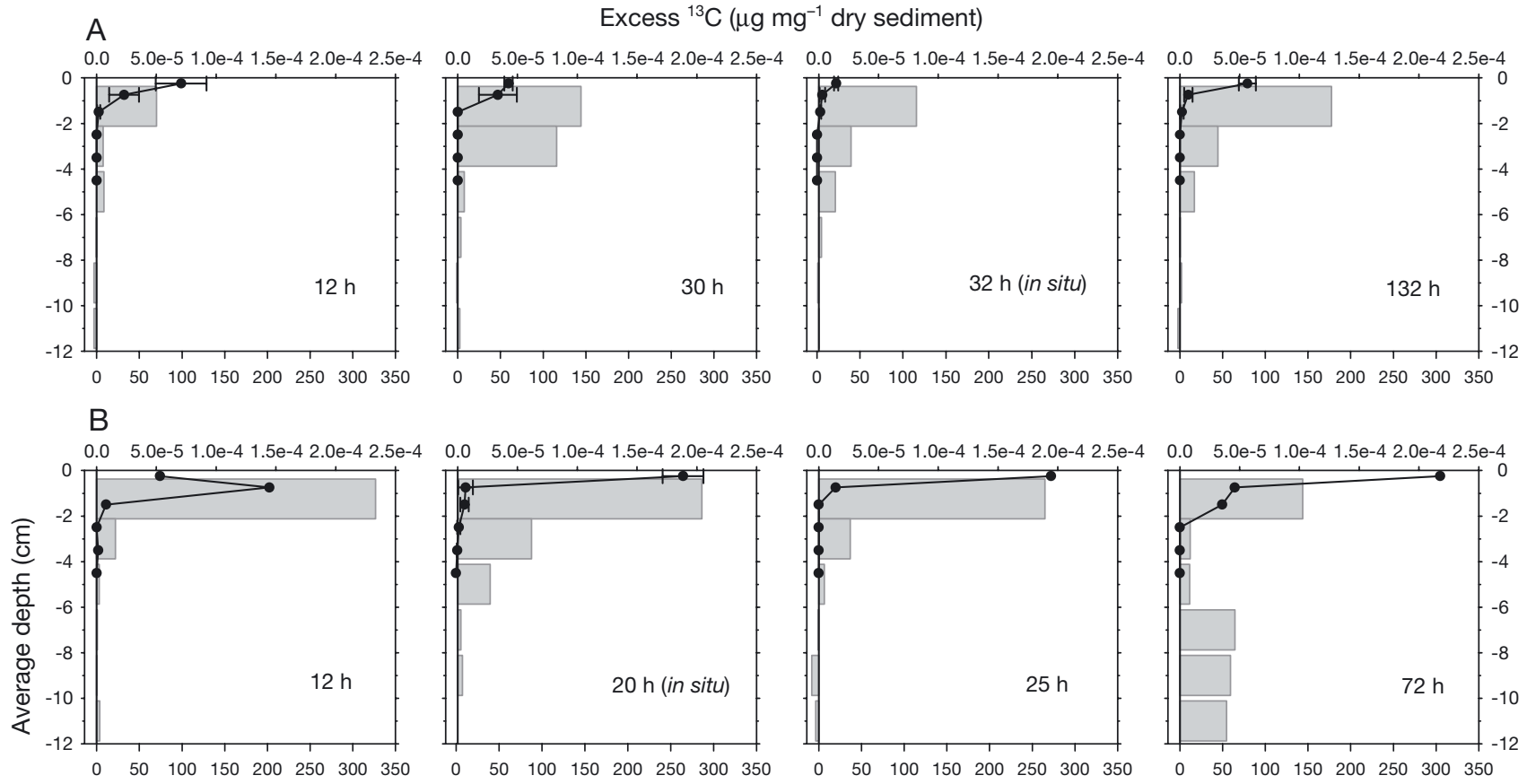

C

D. brightwellii $\left(\times 10^{3}\right.$ cells $\left.\mathrm{ml}^{-1}\right)$

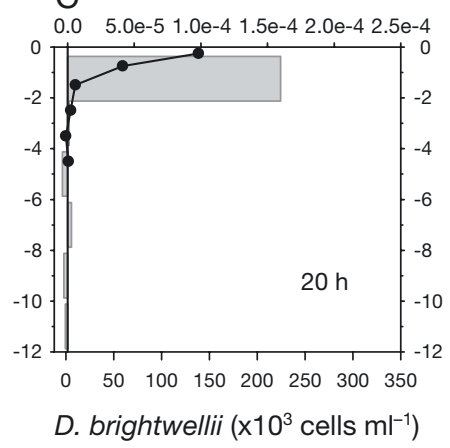

Fig. 6. Transport of ${ }^{13} \mathrm{C}$-labeled diatoms into (A) fine, (B) medium and (C) coarse sand after different periods of incubation. Upper abscissa scale (bars): $\mathrm{PO}^{13} \mathrm{C}\left(\mu \mathrm{g} \mathrm{mg}{ }^{-1}\right.$ dry sediment); lower abscissa scale (•): Ditylum brightwellii cells $\left(\times 10^{3}\right.$ cells $\mathrm{ml}^{-1}$ sediment) ( \pm range). Fine sand: $\mathrm{n}=2$; medium sand: $\mathrm{n}=1$, except at $20 \mathrm{~h}$ (in situ), when $\mathrm{n}=2$; coarse sand: $\mathrm{n}=1$. For the controls, 3 cores were analyzed. No D. brightwellii cells were detected in any of the sediments

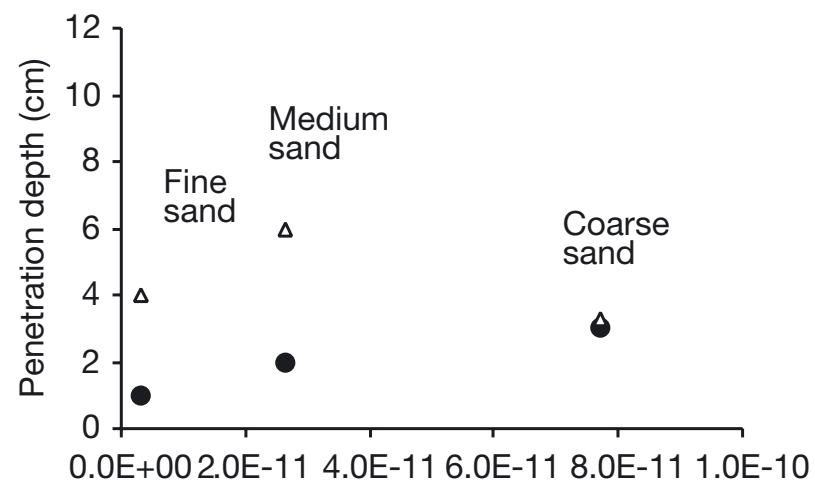

Permeability $\left(\mathrm{m}^{2}\right)$

Fig. 7. Penetration depth of Ditylum brightwellii cells (๑) and $\mathrm{PO}^{13} \mathrm{C}(\boldsymbol{\Delta})$ as a function of sediment permeability. Note different incubation times $(30 \mathrm{~h}$ fine sand, and $20 \mathrm{~h}$ medium and coarse sand), indicating higher penetration depth of algal cells with increasing permeability in less time

\section{DOC, pH and bacterial counts}

DOC in the water (Table 2) was consumed in all experiments (approx. $-1500 \mu \mathrm{mol} \mathrm{m}^{-2} \mathrm{~d}^{-1}$ ), except for the long-time incubation with fine sand, where DOC concentrations increased after $72 \mathrm{~h}$ until the end of the experiment $\left(+7183 \mu \mathrm{mol} \mathrm{m} \mathrm{m}^{-2} \mathrm{~d}^{-1}\right)$. The lowest decrease of $\mathrm{pH}$ was observed for the medium sand, which also had the lowest bacterial growth in the water during the first day (Table 2). The highest increase in bacterial numbers within the first day occurred in the water of the fine-sand incubations.

\section{DISCUSSION}

The incorporation of suspended pelagic diatoms into the sediment usually requires the settling of the algae onto the sediment surface, and then the transfer of the deposited material into deeper layers by biological 
(Huettel 1990) or hydrodynamical (Jenness \& Duineveld 1985) sediment mixing. In permeable sediments, flow-induced advective transport can additionally enhance the deposition of suspended algae by direct transfer from the boundary layer into the bed (Huettel et al. 1996).

Planktonic diatom species, dominated by Coscinodiscus spp., were present in all investigated sands (Figs. 2 \& 3). The maximum penetration depth of Coscinodiscus spp. increased with increasing sediment permeability (Fig. 2). This indicates enhanced advective transport of these planktonic diatoms into the highly permeable sands, as could be confirmed by our chamber experiments. Broken parts of diatom frustules from mainly centric species such as Coscinodiscus spp. and Thalassiosira sp. (the latter dominated the diatom spring bloom in 2001; Ehrenhauss et al. 2004), were abundant in the medium and coarse sands. As the surficial sediments are frequently mobilized due to tidal flow and waves (Antia 1993), the motion of the sand grains may break up the diatom frustules, leading to fast decomposition of the organic material in these dynamic sediments. A more detailed interpretation of the data is not possible, as we do not have any information about the sediment history.

The pennate diatom species were dominated by the epipsammic diatom Plagiogramma brockmanni in all 3 sands (Fig. 3). P. brockmanni has been reported as being abundant during the spring bloom in the plankton near the Frisian Islands (Drebes 1974, Lo 1999). Thus, we do not know if the P. brockmanni cells we found lived as benthic form in the sediment or originated from the water column. Under epifluorescence microscopy, chlorophyll autofluorescence was present in the bulk of the cells, indicating their living state; however, the non-growing vegetative cells of many diatoms have a long survival time in dark and cold environments (Smayda \& Mitchell-Innes 1974). No data are available on the light intensity reaching the sediments, but the seafloor in the southern North Sea is a relatively low-light environment (Jerlov 1951). Nevertheless, light may reach the seafloor occasionally in these shallow depths, e.g. on bright summer days. Studies on the continental shelf of the South Atlantic Bight $(14$ to $40 \mathrm{~m})$ revealed that benthic microalgae, which were dominated by diatoms (Nelson et al. 1999), contributed an average of $37 \%$ to the total primary production (Jahnke et al. 2000). Thus, further studies on light penetration to the North Sea floor, benthic primary production and sedimentation rates of phytoplankton will be needed to enlighten these processes.

The vertical distribution of Plagiogramma brockmanni in the fine sand with a subsurface maximum at $1.5 \mathrm{~cm}$ may be caused by algal growth, or by the incorporation of the diatoms by moving sediment ripples
(Jenness \& Duineveld 1985), which causes typical stripes in up to $5 \mathrm{~cm}$ depth in the sediment at the base of the ripples. The vertical distribution of P. brockmanni in the medium sand did not show stripes, but rather a typical distribution such as caused by advection (Huettel \& Rusch 2000). According to Huettel \& Gust (1992), advective transport processes may be limited to the upper $2 \mathrm{~cm}$ of the fine sand, whereas this pressure-driven pore water flow can be effective to more than $8 \mathrm{~cm}$ depth in the medium and coarse sand. This would explain the higher penetration depth of $P$. brockmanni in these sands. Furthermore, the depth in which the longest diatom chains could be found and the maximum chain lengths recorded in the sediment increased with increasing permeability (Fig. 4). These results indicate a positive relationship between sediment permeability and sand grain size with the maximum penetration depth of single $P$. brockmanni cells or chains (Fig. 5). A negative relationship between the proportion of fine sediments and benthic microalgal biomass in shallow-water ecosystems has been shown by Cahoon et al. (1999).

The fine sand had the lowest diversity of pennate diatom species, containing only Plagiogramma brockmanni and Navicula spp., whereas all 4 pennate species were found in the medium and coarse sand. As the phytoplankton composition and abundances in the water column did not differ between stations (Ehrenhauss et al. 2004), the lower diversity of diatoms in the fine sand could be related to different sediment characteristics. Nitzschia spp. and Raphoneis amphiceros are relatively big diatom species, with a maximum cell size of 120 and $90 \mu \mathrm{m}$, respectively, which could explain their absence from the fine sand (no advective filtration possible).

The experiments showed a fast decrease in the number of added diatom cells in the water (Table 2) resulting from gravitational settling and transport of suspended Ditylum brightwellii cells into deeper layers of the permeable sediments (Fig. 6). The penetration depths of diatom frustules and carbon into the sediment increased with increasing sediment permeability and sand grain size (Figs. $6 \&$ 7), except for the coarse sand where excess ${ }^{13} \mathrm{C}$ was only found in the upper $3 \mathrm{~cm}$. This may have been caused by local sediment inhomogeneities. The coarse sand was not as efficient as trap for diatom cells and carbon as would be expected from its much higher permeability and sand grain size compared to the medium sand (Table 1). The deposition of particles into permeable sediments requires not only the delivery of particles, but also their retention. Fries \& Trowbridge (2003) observed that enhanced fine-particle deposition to permeable sediments depends on the ratio of bed grain size to particle diameter. With increasing permeability of the 
sand bed, the delivery of particles is enhanced. However, without efficient filtration, a larger particle supply does not necessarily translate to enhanced particle deposition. The importance of interactions between particles and sand grains in the retention of delivered particles can be an explanation for the relatively equal deposition of diatom cells in deeper sediment layers of the medium and coarse sand after $20 \mathrm{~h}$ (Table 3).

The distribution of excess ${ }^{13} \mathrm{C}$ in the fine and medium sand always exceeded the maximum penetration depth of diatom frustules. Excess ${ }^{13} \mathrm{C}$ includes not only diatom cells, but also broken parts of the cells (which could not be detected by microscopic observations) and also the incorporation of algal ${ }^{13} \mathrm{C}$ into bacteria and meiofauna. High amounts of diatom carbon were found in deeper layers (6 to $12 \mathrm{~cm}$ ) of the medium sand after $72 \mathrm{~h}$. As the velocity of the advective flow decreases with increasing depth, the penetration of the algae into the sediment is limited (Huettel \& Rusch 2000). Algae accumulate in a layer where pore water moves too slowly to overcome the friction between the cells and sand grains, producing a subsurface maximum. In their labeling study on a sandy and silty intertidal site, Middelburg et al. (2000) showed a faster mixing of algal ${ }^{13} \mathrm{C}$ into deeper sediment layers of the sandy sediment compared to the muddy sediment. A higher flux of algal cells (Dunaliella sp.) into the sediment with increasing permeability was demonstrated by Huettel \& Rusch (2000). Pilditch et al. (1998) also observed that coarser sediments can be a larger sink for diatoms, when boundary flows interact with biogenic structures.

With increasing grain size of the sand bed, a larger volume of water is forced through the sediment. Due to increasing interfacial flows and the larger interstices between the sand grains, the medium and coarse sands were larger sinks for diatoms than the fine sand. Particles trapped in deeper sediment layers cannot be easily removed again from the sediment by upwelling pore water, as the flow velocity decreases with increasing depth, and relatively high pore water flows are needed to dislocate trapped material (Huettel \& Rusch 2000). Our data furthermore demonstrated that due to reduced retention efficiency, the high sediment permeability and sand grain size of the coarse sand did not lead to higher particle deposition.

The lower penetration depth of Ditylum brightwellii compared to Coscinodiscus spp. may be caused by the relatively short incubation time and lower advective pore water flows in the experiments compared to in situ conditions. The intensity of the advective water flows depends on sediment permeability (Huettel \& Gust 1992), flow velocity (Forster et al. 1996) and topography height (Huettel et al. 1996). The pressure gradient in our stirred chambers (approx. 0.2 $\mathrm{Pa} \mathrm{cm}^{-1}$ ) is comparable to the pressure gradient at sediment ripples of $2 \mathrm{~cm}$ height exposed to bottom currents of $10 \mathrm{~cm} \mathrm{~s}^{-1}$ at $10 \mathrm{~cm}$ above the sediment surface (Huettel $\&$ Rusch 2000). Tidal current velocities at our study site are in the range of 30 to $60 \mathrm{~cm} \mathrm{~s}^{-1}$ at $100 \mathrm{~cm}$ above the sediment surface (Antia 1993), but consequently lower at $10 \mathrm{~cm}$ above the sediment. Roughness elements of approximately 1 to $4 \mathrm{~cm}$ height were always present at the sediment surface of all 3 stations (F. Janssen unpubl. data). Thus, advective pore water exchange and coherent transport of diatoms inside the chambers would lie in the lower range of rates obtained under natural conditions.

Penetration depth is additionally determined by the size, shape and surface characteristics of the diatom cells (Huettel \& Rusch 2000). The cell size of Coscinodiscus spp. and Ditylum brightwellii lies in the same range (approx. $100 \mu \mathrm{m}$ ), but the shape of these diatoms differs. Coscinodiscus spp. has a discoidal shape, whereas $D$. brightwellii has an elongated, prismatic shape with a long spine on both sides, which most probably caused its lower penetration depth compared to Coscinodiscus spp. As the majority of coastal bloom diatoms are chain-forming and spiny (Smetacek 1985), these characteristics may not only serve as an antipredation device, but also reduce benthic filtration.

Sediment mixing associated with the feeding activities of benthic macrofauna may have also accounted for particle transport into the sediment. Laboratory chamber experiments on the fine sand with Fabulina fabula (Bivalvia, Tellinidae), the dominant macrofauna species at our fine station, revealed that advection was responsible for the transport of algal material down to $2 \mathrm{~cm}$ depth (Kamp 2002). The presence of $F$. fabula led additionally to the deposition of algae down to 5 to 7 $\mathrm{cm}$ depths. Macrofauna biomass was significantly lower in the chambers with medium and coarse sand than in those with fine sand (U. Witte et al. unpubl. data). Therefore, bioturbation seems to be less important for solute and particle transport in the coarsegrained sands. Marinelli et al. (1998) found that advection also was the dominant solute transport process in the upper sediment layers of sandy sediments of the South Atlantic Bight, which had a comparable permeability and sand grain size as our medium and coarse sand.

As our study site represents a highly dynamic environment, the question arises as to whether moving sediment ripples can bury or remove algae after deposition. Jenness \& Duineveld (1985) demonstrated that moving sediment ripples alternately buried algae in sandy North Sea sediments, and released the material again. However, Jenness \& Duineveld (1985) also stated that transient deposited algae may provide a food source for benthic organisms. In our chamber 
experiments, uptake of deposited algal ${ }^{13} \mathrm{C}$ into bacteria and macrofauna was already visible in the shortest incubation of $12 \mathrm{~h}$ (Kamp 2002, S. I. Bühring et al. unpubl. data), indicating a fast turnover of algal ${ }^{13} \mathrm{C}$ in these sandy sediments. For fine sand, Kamp (2002) showed that the very abundant (surface) deposit- and suspension-feeder Fabulina fabula was responsible for the highest uptake of algal ${ }^{13} \mathrm{C}$ into macrofauna organisms. Another important species in terms of ${ }^{13} \mathrm{C}$ uptake was the polychaete Lanice conchilega. Because of their ability to feed on suspended particulate matter in the overlying water, F. fabula and L. conchilega showed higher uptake of algal ${ }^{13} \mathrm{C}$ than (surface) deposit-feeders such as Echinocardium cordatum. The dual labeling study of Herman et al. (2000), in which pelagic and benthic algae were labeled with ${ }^{15} \mathrm{~N}$ and ${ }^{13} \mathrm{C}$, respectively, demonstrated also the high importance of pelagic algae as food source for suspension-feeders, whereas (surface) deposit feeders depended mostly on microphytobenthos as food source. Investigations on a mobile ripple-forming intertidal sandy sediment in a Dutch estuary (Herman et al. 2000, 2001) showed that the resuspension of benthic microalgae is relatively limited, which shortens the time period of their availability to suspension-feeders.

Due to enhanced advective transport of ${ }^{13} \mathrm{C}$ enriched diatoms into the medium and coarse sand, the mineralization of the added organic matter was consequently shifted into deeper sediment layers. Total mineralization of the algal carbon to ${ }^{13} \mathrm{CO}_{2}$ was mainly restricted to the upper sediment layer of the fine sand (S. I. Bühring et al. unpubl. data), whereas ${ }^{13} \mathrm{CO}_{2}$ release from the added algal carbon took place over the total depth of $12 \mathrm{~cm}$ in the medium sand (U. Witte et al. unpubl. data).

Remineralization of the algal carbon and release of DOC into the overlying water was not visible during the first $3 \mathrm{~d}$, as DOC was preferentially consumed (Table 2). Sorption of DOC onto mineral surfaces in the sediments (Keil et al. 1994) or onto the chambers walls can be an explanation for the observed DOC decrease. Nevertheless, the DOC decrease (3 to $5 \%$ $\mathrm{d}^{-1}$ of the added algal carbon) and ${ }^{13} \mathrm{CO}_{2}$ release $\left(3.4 \% \mathrm{~d}^{-1}\right.$ of the added algal carbon for the fine sand, S. I. Bühring et al. unpubl. data) were in the same order of magnitude. This indicates that initially the soluble fraction of the added algal carbon (approx. $20 \%$ DOC) was decomposed to $\mathrm{CO}_{2}$ by the increasing bacteria population in the water (Table 2). $\mathrm{pH}$ decreased slightly in the water column above all tested sediments (Table 2), indicating release of $\mathrm{CO}_{2}$ and further formation of bicarbonate and carbonate ions. The high DOC increase in the chambers with fine sand after the third day $\left(7183 \mu \mathrm{mol} \mathrm{m}{ }^{-2} \mathrm{~d}^{-1}\right.$, corresponding to $28 \%$ of the added algal carbon) reveals that subsequently the particulate fraction of the diatom carbon was rapidly decomposed. This may also explain the low amounts of $\mathrm{PO}^{13} \mathrm{C}$ (approx. $5 \%$ ), recovered from the sediment of the chambers (Table 3). Furthermore, the added diatom cells were not all intact due to freezing, which led to release of DOC from the cells (approx. 20\%). Additionally, the diatom carbon was incorporated into macrofauna (Kamp 2002) and probably into water-column bacteria, which would also contribute to the low amounts of $\mathrm{PO}^{13} \mathrm{C}$ found in the sediments. Intact and parts of diatom frustules were still abundant in the sediment, as the dissolution of opal by mainly inorganic dissolution is relatively slow.

\section{CONCLUSIONS}

We have shown that advective interfacial flows carry suspended planktonic diatoms into deeper layers of permeable North Sea sediments. The magnitude and penetration depth of diatoms thereby depends on sand grain size, sediment permeability, diatom cell size, shape and chain length. We propose that colony formation and spines of coastal bloom diatoms may also be an adaptation to reduce benthic filtation, as permeable sediments may advectively filter $100 \mathrm{l} \mathrm{m}^{-2} \mathrm{~d}^{-1}$ (Precht \& Huettel 2003). Advective filtration rates within our experimental chambers were most probably a conservative estimate of natural conditions, as near-bottom current velocities can be higher (Antia 1993), as well as the seabed topography. Our results support the view that permeable sediments have a high filtration capability, trap suspended planktonic diatoms, and thus prevent their resuspension by strong bottom currents and waves. Trapped in the sediment, these algae are most probably rapidly degraded, as observed in our experiment, where $28 \%$ of the added diatom carbon was released as DOC d $\mathrm{d}^{-1}$ after the third incubation day. Boon et al. (1998) also demonstrated that a substantial part (up to $40 \%$ ) of the primary production was buried and subsequently degraded in non-depositional areas of the southern and central North Sea. Further studies are needed to resolve these processes, which are a major issue in carbon and nutrient recycling in shelf sediments.

Acknowledgements. We thank B. B. Jørgensen for the support of this work. F. Janssen, A. Kamp, V. Meyer and our divers are gratefully acknowledged for their help during the cruises. We thank the captain and crew of RV 'Heincke' for their assistance on the 3 expeditions. U. Struck (University of Munich) is acknowledged for the $\mathrm{PO}^{13} \mathrm{C}$ measurements. We thank A. Kamp for the preparation of the $\mathrm{PO}^{13} \mathrm{C}$ samples and H. Jonkers for his help with the DOC measurements. A. Pern- 
thaler is acknowledged for providing an axenic clone of Ditylum brightwellii. The manuscript was improved by the critical comments of 5 anonymous reviewers. This study was supported by the Max Planck Society.

\section{LITERATURE CITED}

Antia EE (1993) Sedimentology, morphodynamics and facies association of a mesotidal barrier island shoreface (Spiekeroog, southern North Sea). PhD thesis, University of Bremen

Antia EE (1995) Sedimentary deposits related to inletshoreface storm flow interaction in the German Bight. Estuar Coast Shelf Sci 40:699-712

Bacon MP, Belastock RA, Bothner MH (1994) ${ }^{210} \mathrm{~Pb}$ balance and implications for particle transport on the continental shelf, US Middle Atlantic Bight. Deep-Sea Res II 41: 511-535

Boon AR, Duineveld GCA, Berghuis EM, van der Weele JA (1998) Relationships between benthic activity and the annual phytopigment cycle in near-bottom water and sediments in the southern North Sea. Estuar Coast Shelf Sci 46:1-13

Brussaard CPD, Riegman R, Noordeloos AAM, Cadée GC and 5 others (1995) Effects of grazing, sedimentation and phytoplankton cell lysis on the structure of a coastal pelagic food web. Mar Ecol Prog Ser 123:259-271

Cahoon LB, Nearhoof JE, Tilton CL (1999) Sediment grain size effect on benthic microalgal biomass in shallow aquatic ecosystems. Estuaries 22:735-741

Craig H (1957) Isotopic standards for carbon and oxygen and correction factors for mass-spectrometric analysis of carbon dioxide. Geochim Cosmochim Acta 12:133-149

Creutzberg F, Postma H (1979) An experimental approach to the distribution of mud in the southern North Sea. Neth J Sea Res 13:99-116

Drebes G (1974) Marines phytoplankton. Georg Thieme, Stuttgart

Ehrenhauss S, Witte U, Janssen F, Huettel M (2004) Decomposition of diatoms and nutrient dynamics in permeable North Sea sediments. Contin Shelf Res 24(6):721-737

Forster S, Huettel M, Ziebis W (1996) Impact of boundary layer flow velocity on oxygen utilization in coastal sediments. Mar Ecol Prog Ser 143:173-185

Fries JS, Trowbridge JH (2003) Flume observations of enhanced fine-particle deposition to permeable sediment beds. Limnol Oceanogr 48:802-812

Goering JC, Patton CJ, Shields WW (1973) Nutrient cycles. Occas Publ Inst Mar Sci Univ Alaska 2:253-271

Grant J, Emerson CW, Hargrave BT, Shortle JL (1991) Benthic oxygen consumption on continental shelves off eastern Canada. Cont Shelf Res 11:1083-1097

Grasshoff K, Kremling K, Ehrhardt M (1999) Methods of seawater analysis, 3 edn. Wiley-VCH, Weinheim

Guillard RRL, Ryther JH (1962) Studies of marine planktonic diatoms. 1. Cyclotella nana hustedt and Detonula confervacea (Cleve) Gran. Can J Microbiol 8:229-239

Herman PMJ, Middelburg JJ, Widdows J, Lucas CH, Heip CHR (2000) Stable isotopes as trophic tracers: combining field sampling and manipulative labelling of food resources for macrobenthos. Mar Ecol Prog Ser 204:79-92

Herman PMJ, Middelburg JJ, Heip CHR (2001) Benthic community structure and sediment processes on an intertidal flat: results from the ECOFLAT project. Cont Shelf Res 21: 2055-2071

Huettel M (1990) Influence of the lugworm Arenicola marina on porewater nutrient profiles of sand flat sediments. Mar Ecol Prog Ser 62:241-248

Huettel M, Gust G (1992) Impact of bioroughness on interfacial solute exchange in permeable sediments. Mar Ecol Prog Ser 89:253-267

Huettel M, Rusch A (2000) Transport and degradation of phytoplankton in permeable sediment. Limnol Oceanogr 45:534-549

Huettel M, Webster IT (2001) Porewater flow in permeable sediments. In: Boudreau BP, Jørgensen BB (eds) The benthic boundary layer. Oxford University Press, Oxford, p 144-179

Huettel M, Ziebis W, Forster S (1996) Flow-induced uptake of particulate matter in permeable sediments. Limnol Oceanogr 41:309-322

Huettel M, Ziebis W, Forster S, Luther GW (1998) Advective transport affecting metal and nutrient distributions and interfacial fluxes in permeable sediments. Geochim Cosmochim Acta 62:613-631

Jahnke RA, Nelson JR, Marinelli RL, Eckman JE (2000) Benthic flux of biogenic elements on the southeastern US continental shelf: influence of pore water advective transport and benthic microalgae. Cont Shelf Res 20:109-127

Jenness MI, Duineveld GCA (1985) Effects of tidal currents on chlorophyll a content of sandy sediments in the southern North Sea. Mar Ecol Prog Ser 21:283-287

Jerlov NG (1951) Optical studies of ocean water. Rep Swed Deep Sea Exped 3:1-59

Kamp A (2002) Die Bedeutung der Makrofauna für den Kohlenstofffluss in permeablen Schelfsedimenten (Nordsee): Experimente mit isotopenmarkiertem Phytoplankton. MS thesis, University of Bremen

Keil RG, Montluçon DB, Prahl FG, Hedges JI (1994) Sorptive preservation of labile organic matter in marine sediments. Nature 370:549-552

Levin L, Blair N, DeMaster D, Plaia G, Fornes W, Martin C, Thomas C (1997) Rapid subduction of organic matter by maldanid polychaetes on the North Carolina slope. J Mar Res 55:595-611

Lo S (1999) Diatomeenblüte in der Nordsee im Frühjahr 1998: Sukzession der Arten in verschiedenen Wassermassen. MS thesis, University of Bremen

Marinelli RL, Jahnke RA, Craven DB, Nelson JR, Eckman JE (1998) Sediment nutrient dynamics on the South Atlantic Bight continental shelf. Limnol Oceanogr 43:1305-1320

Middelburg JJ, Barranguet C, Boschker HTS, Herman PMJ, Moens T, Heip CHR (2000) The fate of intertidal microphytobenthos carbon: an in situ ${ }^{13} \mathrm{C}$ labelling study. Limnol Oceanogr 45:1224-1234

Moodley L, Boschker HTS, Middelburg JJ, Pel R, Herman PMJ, de Deckere E, Heip CHR (2000) Ecological significance of benthic foraminifera: ${ }^{13} \mathrm{C}$ labelling experiments. Mar Ecol Prog Ser 202:289-295

Nelson JR, Eckman JE, Robertson CY, Marinelli RL, Jahnke RA (1999) Benthic microalgal biomass and irradiance at the sea floor on the continental shelf of the South Atlantic Bight: spatial and temporal variability and storm effects. Cont Shelf Res 19:477-505

Pankow H (1990) Ostsee-Algenflora. Gustav-Fischer, Jena

Passow U (1991) Species-specific sedimentation and sinking velocities of diatoms. Mar Biol 108:449-455

Peinert R, Saure A, Stegmann P, Stienen C, Haardt H, Smetacek V (1982) Dynamics of primary production and sedimentation in a coastal ecosystem. Neth J Sea Res 16: 276-289

Pilditch CA, Emerson CW, Grant J (1998) Effect of scallop shells and sediment grain size on phytoplankton flux to 
the bed. Cont Shelf Res 17:1869-1885

Precht E, Huettel M (2003) Advective pore-water exchange driven by surface gravity waves and its ecological implications. Limnol Oceanogr 48:1674-1684

Schrader HJ, Schuette G (1981) Marine diatoms. In: Emiliani C (ed) The oceanic lithosphere: the sea. John Wiley \& Sons, New York, p 1179-1232

Shum KT, Sundby B (1996) Organic matter processing in continental shelf sediments - the subtidal pump revisited. Mar Chem 53:81-87

Smayda TJ (1970) The suspension and sinking of phytoplankton in the sea. Oceanogr Mar Biol Annu Rev 8:353-414

Editorial responsibility: Otto Kinne (Editor), Oldendorf/Luhe, Germany
Smayda TJ, Mitchell-Innes B (1974) Dark survival of autotrophic planktonic marine diatoms. Mar Biol 25: 195-202

Smetacek VS (1985) Role of sinking in diatom life-history cycles: ecological, evolutionary and geological significance. Mar Biol 84:239-251

Utermöhl H (1958) Zur Vervollkommnung der quantitativen Planktonmethodik. Mitt Int Verh Theor Angew Limnol 9: $1-38$

Ziebis W, Huettel M, Forster S (1996) Impact of biogenic sediment topography on oxygen fluxes in permeable seabeds. Mar Ecol Prog Ser 140:227-237

Submitted: March 17, 2003; Accepted: January 27, 2004 Proofs received from author(s): April 13, 2004 